\title{
High expression of CD39 in gastric cancer reduces patient outcome following radical resection
}

\author{
XIAO-YAN CAI ${ }^{*}$, XUE-FEI WANG ${ }^{2 *}$, JUN LI $^{1}$, JIANG-NAN DONG $^{1}$, JIANG-QI LIU $^{1}$, \\ NENG-PING LI ${ }^{1}$, BEI YUN ${ }^{1}$, RONG-LONG XIA ${ }^{1}$, JING QIN ${ }^{2}$ and YI-HONG SUN ${ }^{2}$ \\ ${ }^{1}$ Department of General Surgery, Gongli Hospital, Shanghai 200135; ${ }^{2}$ Department of General Surgery, \\ Zhongshan Hospital, Fudan University, Shanghai 200032, P.R. China
}

Received June 16, 2015; Accepted September 1, 2016

DOI: $10.3892 / \mathrm{ol} .2016 .5189$

\begin{abstract}
Ectonucleoside triphosphate diphosphohydrolase 1 (ENTPD1), also known as cluster of differentiation (CD)39, is the rate-limiting enzyme in the generation of immunosuppressive adenosine and is important in tumor progression. The present study evaluated the expression of $\mathrm{CD}_{3} 9^{+}$and CD39 ${ }^{+}$forkhead box P3 (FoxP3) ${ }^{+}$regulatory $\mathrm{T}$ (Treg) cells in gastric cancer (GC), and determined their prognostic roles in patients with $\mathrm{GC}$ following radical resection. It was observed that CD39 was expressed at significantly higher rates in tumor tissues as compared with paired peritumoral tissues. Overexpression of tumor CD39 was correlated with overall survival (OS). Furthermore, CD39 expression in GC tissues exhibited a prognostic role in $\mathrm{OS}$. The $\mathrm{CD}_{3} 9^{+} \mathrm{FoxP}^{+} / \mathrm{FoxP}^{+}$ratio in tumor tissues was higher than that in paired peritumoral tissues, and $\mathrm{CD}_{39}{ }^{+} \mathrm{FoxP}^{+}$Treg cells were a better prognostic indicator than FoxP $3^{+}$Treg cells for OS. Collectively, our study indicates that overexpression of CD39 in GC is a predictor of poor outcome for GC patients following radical resection. $\mathrm{CD} 3{ }^{+} \mathrm{FoxP}^{+}$Treg cells are a potential target for cancer immunotherapy.
\end{abstract}

\section{Introduction}

Gastric cancer (GC) is the fourth most frequent type of cancer and results in millions of mortalities worldwide (1). Due to advances in surgery and chemotherapy, the incidence of GC has declined in the past years (1); however, recurrence is very

Correspondence to: Dr Xiao-Yan Cai, Department of General Surgery, Gongli Hospital, 219 Miaopu Road, Shanghai 200135, P.R. China

E-mail: cxy6429@sina.com

Dr Jing Qin, Department of General Surgery, Zhongshan Hospital, Fudan University, 180 Fenglin Road, Shanghai 200032, P.R. China

E-mail: qin.jing@zs-hospital.sh.cn

*Contributed equally

Key words: CD39, gastric cancer, prognosis common. Thus, the discovery of new diagnostic and prognostic markers remains urgent.

The role of the immune system in controlling tumor immunogenicity has now been definitely established (2). The immune system has contradictory effects on tumor development, including facilitating cellular transformation, preventing tumor growth and shaping tumor immunogenicity (2). Tumor growth is the result of a process called immunoediting, during which, tumor fate is determined in three phases: Elimination, equilibrium and escape (2). The tumor escape phase is the final phase of the process, in which tumors grow quickly, become clinically apparent and establish an immunosuppressive tumor microenvironment (3). The process of tumor escape occurs through loss of antitumor immunity [cluster of differentiation (CD) $8^{+} \mathrm{T}$ cells, natural killer (NK) cells and NK T cells] and enhancement of pro-tumor immunity [myeloid-derived suppressor cells and regulatory $\mathrm{T}$ (Treg) cells] (4). Numerous molecules have been reported to be involved in immunosuppression, including programmed death-ligand 1, CD151 and transforming growth factor- $\beta$ (5-7).

Ectonucleoside triphosphate diphosphohydrolase 1 (ENTPD1, also known as CD39), a functional surface marker for Treg cells (8), was initially identified as a novel immunoregulatory molecule $(9,10)$. CD39 is an integral membrane protein that metabolizes extracellular adenosine triphosphate (ATP) and adenosine diphosphate (ADP) to adenosine monophosphate (11-13). Previous studies demonstrated that CD39 is expressed in numerous cells, including leukocytes $(14,15)$, Treg cells $(16,17)$ and endothelial cells (18). CD39 dysregulation has been associated with multiple human cancer types, including leukemia (19), colon cancer (20) and pancreatic cancer (21).

Tumorigenesis and cancer development can be considered the result of immune dysregulation (22). GC has been observed to be associated with inflammatory states, which are linked to immune dysregulation. Treg cells in peripheral blood mononuclear cells (PBMCs) increased gradually with tumor stage in GC (23). Ichihara et al reported that Treg cell populations also increased in tumor-infiltrating lymphocytes and PBMCs (24). In addition, Treg cells were associated with adverse prognosis in radically resected GC (25). However, as a surface marker for Treg cells (26), the role of CD39 has not been explored sufficiently; there has been no description of CD39 expression in human GC tissue, and its prognostic role has not been elucidated. 
In the present study, the expression of CD39 and forkhead box P3 (FoxP3) was determined in 101 GC patients using double immunohistochemistry (IHC), and a higher expression of CD39 and cell counts of $\mathrm{CD} 9^{+} \mathrm{FoxP}^{+}$was identified in gastric tumor tissues compared with paired adjacent tissues. Additionally, high CD39 expression was associated with poor prognosis in resected GC patients. The level of tumor $\mathrm{CD} 9^{+}$FoxP $^{+}$Treg cells was also associated with overall survival (OS).

\section{Materials and methods}

Patients and tissue microarray (TMA). TMA involved 101 patients who underwent radical resection of GC at the Department of General Surgery, Zhongshan Hospital (Shanghai, China) between January 2003 and June 2008. Patients were selected under the following inclusion criteria: i) Confirmed pathological diagnosis of GC; ii) no preoperative anticancer treatment or signs of distant metastasis; and iii) integrated clinicopathological characteristics and postoperative follow-up data. Written informed consent from patients was obtained with the approval of the ethics committee of Fudan University (Shanghai, China). OS was censored at the final follow-up visit (on December 31, 2014).

IHC. IHC was performed by the streptavidin-biotin method. Formalin-fixed, paraffin-embedded, 4- $\mu$ m-thick sections were deparaffinized, followed by antigen retrieval. The sections were incubated with rabbit anti-human CD39 (cat. no. HPA014076; 1:200; Sigma-Aldrich; Merck Millipore, Darmstadt, Germany) and mouse anti-human FoxP3 (cat. no. 320102; 1:200; BioLegend, Inc., San Diego, CA, USA) primary antibodies overnight at $4^{\circ} \mathrm{C}$. 3,3'-Diaminobenzidine tetrahydrochloride and hematoxylin were used for counterstaining.

Double IHC for CD39 and FoxP3. Double staining for CD39 and FoxP3 was performed in all cases. A positive anti-human CD39 or anti-human FoxP3 staining result was blue or red, respectively. Double positive staining was purple.

Quantification methods. The number of CD39+ cells was counted in a $1-\mathrm{mm}$ diameter cylinder using a microscopic field at x100 magnification. Three areas with the most abundant distribution were selected in each case. Positive staining was evaluated by mean optical density, which corresponded to the positive staining intensity of CD39. The number of FoxP3-positive cells and both CD39- and FoxP3-positive cells in the 1-mm diameter cylinder were counted by two experienced pathologists under high-power magnification (x400). The mean count of the triplicate values (cells/spot) was calculated.

Cell lines. Five human gastric cancer cell lines, including HGC27, BGC823, MKN45, AGS and SGC7901, and a gastric epithelial cell line GES-1, were purchased from the Cell Bank of the Chinese Academy of Sciences (Shanghai, China) and cultured in RPMI-1640 medium supplemented with $10 \%$ fetal bovine serum (Sijiqing Biological Engineering Materials Co., Ltd., Hangzhou, China) in a $5 \% \mathrm{CO}_{2}$ incubator at $37^{\circ} \mathrm{C}$.
Table I. Univariate analysis of clinicopathological characteristics in gastric cancer $(n=101)$.

\begin{tabular}{|c|c|}
\hline Variables & $\begin{array}{c}\text { OS univariate } \\
\text { P-value }\end{array}$ \\
\hline \multicolumn{2}{|l|}{ TMA assays } \\
\hline Age, years $(\leq 60 />60)$ & 0.126 \\
\hline Gender (male/female) & 0.850 \\
\hline Location (U/M/D) & 0.295 \\
\hline Tumor size, $\mathrm{cm}(\leq 3 />3)$ & 0.387 \\
\hline Histology (good/poor) & 0.708 \\
\hline Lauren score (intestinal/diffuse) & 0.200 \\
\hline Tumor differentiation (I/II/III) & 0.204 \\
\hline $\mathrm{T}(1 / 2 / 3 / 4)$ & $<0.001$ \\
\hline N (no/yes) & $<0.001$ \\
\hline M (no/yes) & $<0.001$ \\
\hline TNM stage (0/I/II/III/IV) & $<0.001$ \\
\hline \multicolumn{2}{|l|}{ Mean expression or counts (low/high) } \\
\hline t-density-mean CD39 & 0.032 \\
\hline t-FoxP3 & 0.042 \\
\hline t-double-CD39-FoxP3 & 0.034 \\
\hline p-density-mean CD39 & 0.080 \\
\hline p-FoxP3 & 0.163 \\
\hline p-double-CD39-FoxP3 & 0.147 \\
\hline
\end{tabular}

OS, overall survival; TMA, tissue microarray; U, upper; $\mathrm{M}$, middle; D, duodenum; TNM, tumor-node-metastasis; CD, cluster of differentiation; t, tumor; p, peritumor; FoxP3, forkhead box P3.

RNA isolation and reverse transcription-quantitative polymerase chain reaction ( $R T-q P C R)$. Total RNA from cultured cells was isolated using TRIzol reagent (Thermo Fisher Scientific, Inc., Waltham, MA, USA) according to the manufacturer's protocol. Complementary DNA was synthesized using the PrimeScript RT Reagent kit (Takara Biotechnology Co., Ltd., Dalian, China). CD39 expression was determined using SYBR Premix Ex Taq (Takara Biotechnology Co.) and primers designed according to Primer 3.0 software (Whitehead Institute for Biomedical Research, Cambridge, MA, USA). Primer sequences were as follows: CD39 human forward 5'-CTGATT CCTGGGAGCACATC-3' and reverse 5'-CTGGGATCATGT TGGTCAGG-3'. PCR was performed under the following conditions: Denaturation at $95^{\circ} \mathrm{C}$ for $2 \mathrm{~min}$ followed by 40 cycles of annealing at $95^{\circ} \mathrm{C}$ for $10 \mathrm{sec}$ and $60^{\circ} \mathrm{C}$ for $30 \mathrm{sec}$ and extension at $72^{\circ} \mathrm{C}$ for $30 \mathrm{sec}$. The messenger RNA expression level of $\beta$-actin was used for normalization, and the relative CD39 expression levels were measured by the $2^{-\Delta \Delta \mathrm{Cq}}$ method (27).

Western blot analysis. Immunoblotting was carried out as previously described (25). In brief, cells were lysed in ice-cold RIPA buffer (Santa Cruz Biotechnology, Inc., Dallas, TX, USA) and proteins were quantified using the Pierce BCA Protein Assay kit (Thermo Fisher Scientific Inc.). Approximately $30 \mathrm{mg}$ of protein extracted from the six cell lines was separated by $10 \%$ sodium dodecyl sulfate polyacrylamide gel electrophoresis. The proteins were then transferred to a polyvinylidene fluoride membrane 
A
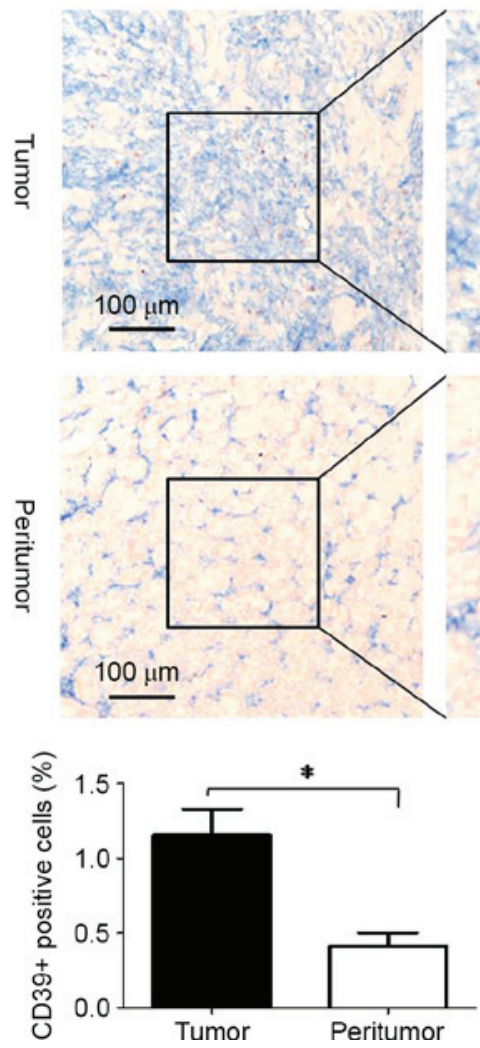

B

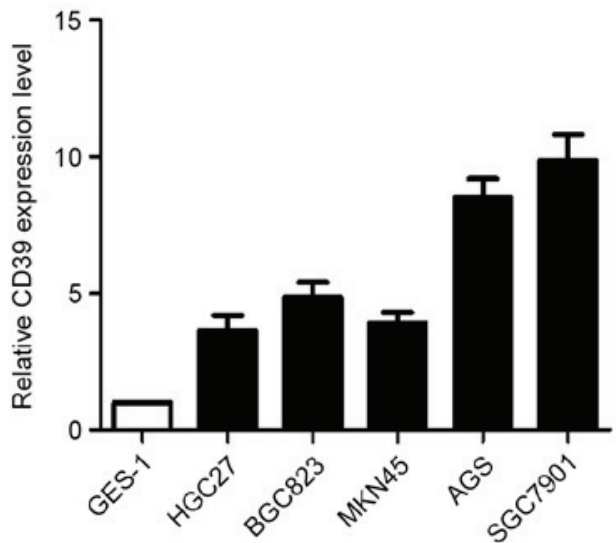

C

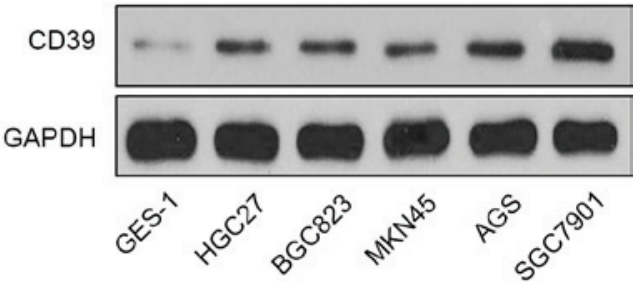

Figure 1. CD39 expression in tumor and paired peritumoral tissues and in GC cell lines. (A) CD39 expression (blue) in tumor tissue was higher than that in paired peritumoral tissue. Statistical graphs of CD39-positive cells are also presented. ${ }^{*} \mathrm{P}=0.0363$. CD39 expression in five GC cell lines was detected by (B) reverse transcription-quantitative polymerase chain reaction and (C) western blotting. CD, cluster of differentiation; GAPDH, glyceraldehyde 3-phosphate dehydrogenase; GC, gastric carcinoma.

(EMD Millipore, Billerica, MA, USA), incubated with 5\% skim milk powder for $1 \mathrm{~h}$ at room temperature then incubated with rabbit anti-human CD39 (cat. no. sc-33558; 1:1,000; Santa Cruz Biotechnology, Inc.) antibody overnight at $4^{\circ} \mathrm{C}$. Following incubation with horseradish peroxidase-conjugated goat anti-rabbit IgG secondary antibody (cat. no. 7074; 1:10,000; Cell Signaling Technology, Inc., Beverly, MA, USA) at $37^{\circ} \mathrm{C}$ for $2 \mathrm{~h}$, bound proteins were visualized using enhanced chemiluminescence (Pierce; Thermo Fisher Scientific, Inc.). Anti-glyceraldehyde 3-phosphate dehydrogenase (cat. no. sc-47724; 1:3,000; Santa Cruz Biotechnology, Inc.) was used as an internal control.

Statistical analysis. Analysis of clinicopathological characteristics in gastric cancer was carried out using the paired t-test. The correlation between CD39 expression and clinicopathological characteristics was performed using $\chi^{2}$ test. For the univariate analyses, Kaplan-Meier curves were performed, and the log-rank test was used for comparison. Cox multivariate analysis was used to adjust for potentially confounding variables and to determine independent prognostic factors. $\mathrm{P}<0.05$ was considered to indicate a statistically significant difference. All analyses were performed using SPSS statistical software version 13.0 (SPSS, Inc., Chicago, IL, USA).

\section{Results}

Clinical profiles of the patients. A total of 101 patients [average age, 60.00 years; age range, 32-80 years; standard deviation (SD), 11.18 years] were included in the analysis. Of these, 6 patients $(5.94 \%)$ were stage I, 36 (35.64\%) were stage II and $59(58.42 \%)$ were stage III. At the final follow-up visit, $31(30.69 \%)$ patients had succumbed to the disease, while $70(69.31 \%)$ were still alive. The OS was 77.00 months (range, 5-139 months; SD, 11.18 months). The mean follow-up period was 5.19 years (range, 0.07-11.36 years; SD, 3.00 years).

Expression of CD39 in GC. CD39 is a marker of Treg cells that is involved in the prognosis and outcome of GC (26). The present study detected CD39 expression in GC tissue samples. As shown in Fig. 1A, positive CD39 staining was blue and was principally scattered in tumor tissues as compared with paired adjacent tissues, which is also represented in the statistical graphs, indicating CD39 overexpression in GC. To confirm this finding, five human GC cell lines (HGC27, BGC823, MKN45, AGS and SGC7901) and a gastric epithelial cell line (GES-1) were used to detect CD39 expression. CD39 expression levels, as detected by RT-qPCR and western blotting, in the five GC cell lines were significantly higher than those in the gastric epithelial cell line (Fig. 1B and C), suggesting that CD39 is highly expressed in GC tissue compared with paired adjacent tissue.

Correlations between CD39 expression and clinicopathological characteristics of GC. Clinicopathological factors such as age, gender, histology, location and Lauren score 
Table II. Multivariate analysis of the correlation between clinicopathological characteristics and CD39 expression, demonstrating the independent risk factors for cancer-specific mortality of patients with gastric cancer $(n=101)$.

\begin{tabular}{|c|c|c|c|c|c|c|}
\hline \multirow[b]{2}{*}{ Characteristics } & \multicolumn{3}{|c|}{ Tumor CD39 expression } & \multicolumn{3}{|c|}{ Peritumor CD39 expression } \\
\hline & Low & High & P-value & Low & High & P-value \\
\hline Age, years & & & 0.625 & & & 1.000 \\
\hline$\leq 60$ & 12 & 39 & & 21 & 30 & \\
\hline$>60$ & 9 & 41 & & 20 & 30 & \\
\hline Gender & & & 0.209 & & & 0.062 \\
\hline Male & 16 & 48 & & 22 & 42 & \\
\hline Female & 5 & 32 & & 20 & 17 & \\
\hline Tumor size, $\mathrm{cm}$ & & & 1.000 & & & 0.039 \\
\hline$\leq 3$ & 13 & 49 & & 31 & 31 & \\
\hline$>3$ & 8 & 31 & & 11 & 28 & \\
\hline Histology & & & 0.339 & & & 1.000 \\
\hline Good & 12 & 36 & & 18 & 32 & \\
\hline Poor & 9 & 44 & & 20 & 33 & \\
\hline Lauren & & & 0.578 & & & 0.017 \\
\hline Intestinal & 17 & 58 & & 20 & 48 & \\
\hline Diffuse & 4 & 22 & & 15 & 11 & \\
\hline Tumor differentiation & & & 0.697 & & & \\
\hline I & 2 & 4 & & 1 & 5 & 0.324 \\
\hline II & 8 & 28 & & 14 & 22 & \\
\hline III & 11 & 48 & & 27 & 32 & \\
\hline Survival & & & 0.018 & & & 0.083 \\
\hline Yes & 19 & 51 & & 25 & 45 & \\
\hline No & 2 & 29 & & 17 & 14 & \\
\hline
\end{tabular}

$\mathrm{CD}$, cluster of differentiation.

A

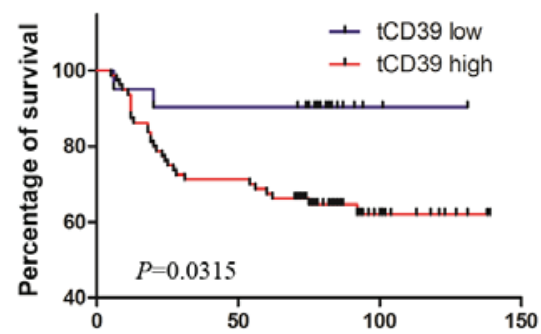

B

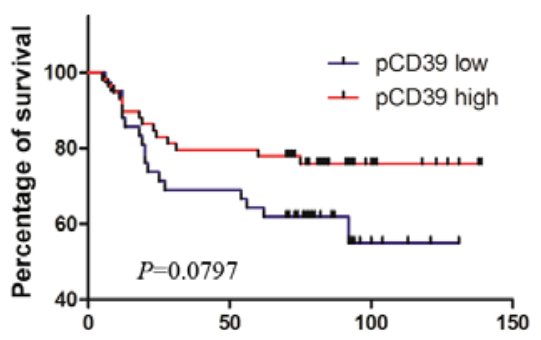

Figure 2. OS analyses of patients with gastric carcinoma based on tCD39 and pCD39 expression. (A and B) Kaplan-Meier analysis of OS regarding (A) tCD39 and (B) pCD39 expression. CD, cluster of differentiation; t, tumor; p, peritumor; OS, overall survival.

exhibited no correlation. In addition, tumor size [risk ratio, 3.0; 95\% confidence interval (CI), 0.3-15.0; $\mathrm{P}=0.387$ ], tumor differentiation (I-III; $\mathrm{P}=0.204)$ and tumor-node-metastasis stage $(0-\mathrm{IV} ; \mathrm{P}=0.003)$ were significantly unfavorable factors in the univariate analysis (Table I). By using the 'minimum P-value' approach, the association between GC clinicopathological characteristics and tumor as well as peritumor CD39 expression was identified. As shown in Table II, peritumor CD39 expression positively correlated with tumor size and intestinal GC. Tumor CD39 expression was an independent poor prognostic factor for OS in patients with GC.

CD39 expression and patient prognosis. Among the $101 \mathrm{GC}$ patients, CD39 expression was divided into low and high expression. The proportion of CD39 high expression in tumor tissue was $79.20 \%$ (80/101), and it was $58.42 \%(59 / 101)$ in peritumor tissue. The Kaplan-Meier curves and log-rank test demonstrated that the OS of patients with high CD39 tumor expression was 
A
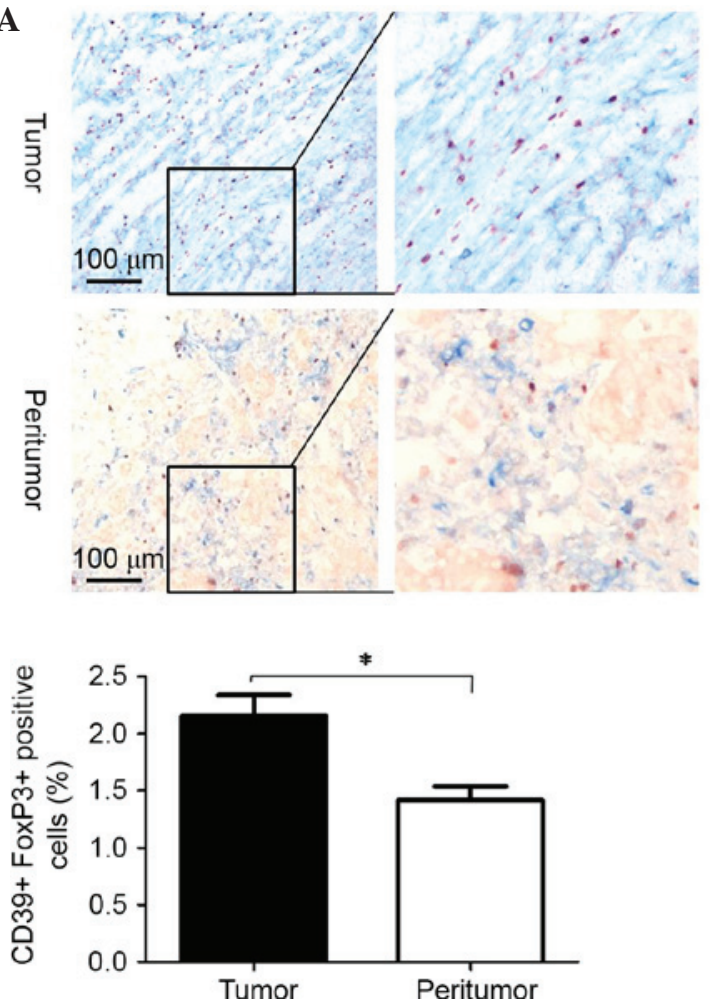

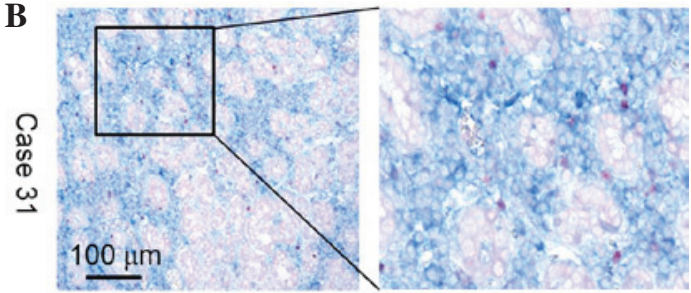

C

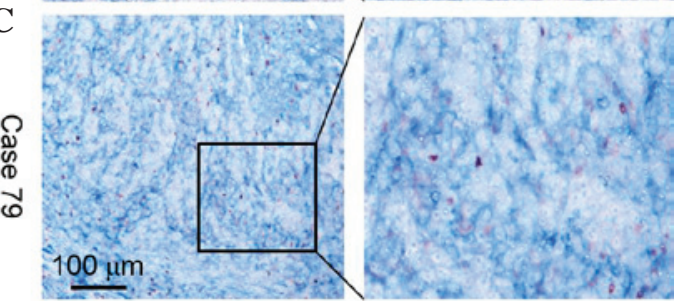

Figure 3. Representative double IHC staining of CD39 and FoxP3. (A) Double IHC staining of CD39 (blue) and FoxP3 (red) in tumor and paired peritumoral tissues. The statistical analysis of $\mathrm{CD} 39^{+} \mathrm{FoxP}^{+}$cells is also presented. ${ }^{*} \mathrm{P}=0.0457$. Two representative cases of tumor tissues are shown in (B) and (C). CD39 ${ }^{+}$ cells are blue, while FoxP3 ${ }^{+}$cells are red and double-positive cells are purple. FoxP3, forkhead box P3; CD, cluster of differentiation; IHC, immunohistochemistry.

A

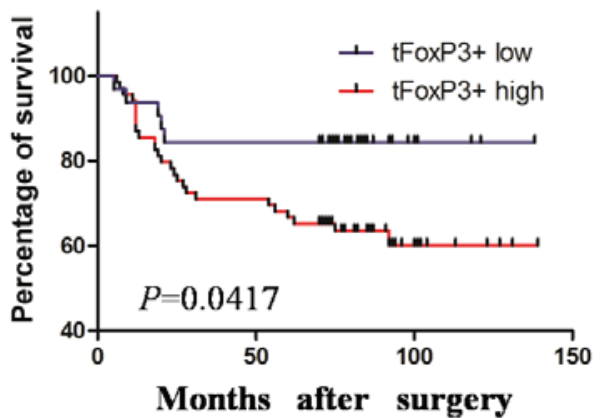

C

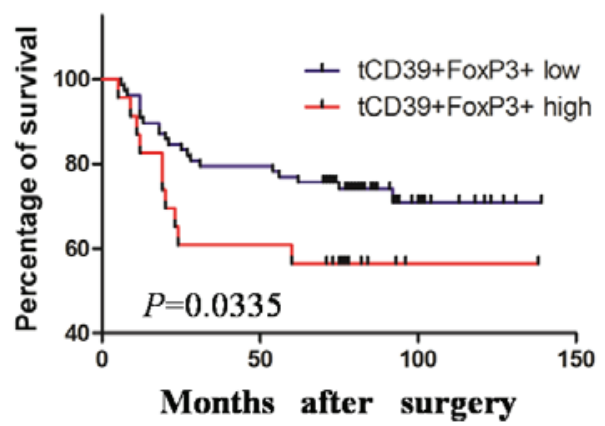

B

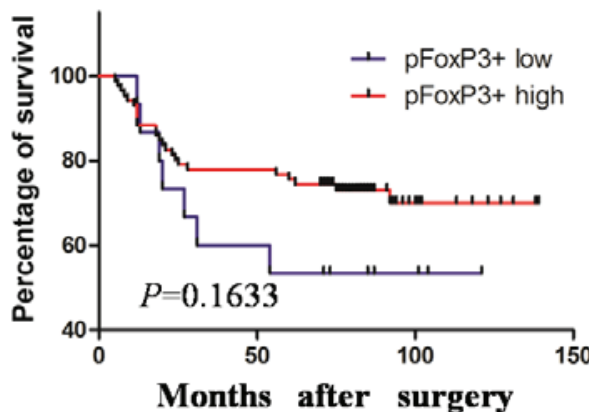

D

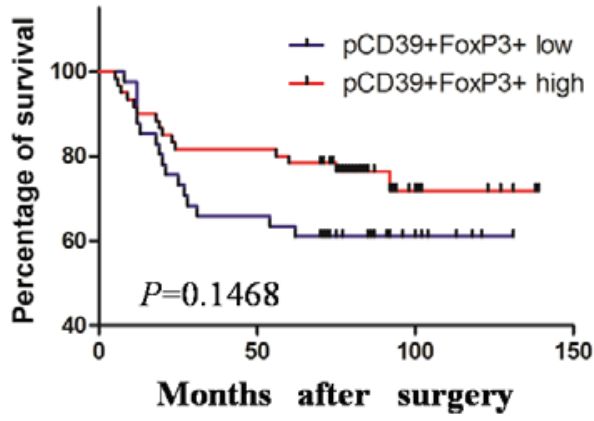

Figure 4. Univariate analyses of the association between cell counts of (A) $\mathrm{tFoxP}^{+}$, (B) $\mathrm{pFoxP}^{+}$, (C) $\mathrm{tCD} 9^{+} \mathrm{FoxP}^{+}$and (D) $\mathrm{pCD}^{2} 9^{+} \mathrm{FoxP}^{+}$and overall survival. CD, cluster of differentiation; t, tumor; p, peritumor; Fox 3 , forkhead box P3.

significantly lower than that of patients with low expression [OS low vs. high, $90.48 \%$ (19/21) vs. 63.75\% (51/80); $\mathrm{P}=0.0315$;
Fig. 2A and Table II], indicating that tumor CD39 expression was an independent poor prognostic factor for OS in GC. However, 
peritumor CD39 expression was not observed to be a prognostic factor (Fig. 2B and Table II). These data demonstrate that tumoral CD39 expression inversely correlates with prognosis in GC.

IHC expression of Fox $3^{+}$and $\mathrm{CD}_{3} 9^{+} \mathrm{FoxP}^{+}$Treg cells in $\mathrm{GC}$. $\mathrm{CD}_{3} 9^{+}$and FoxP3 ${ }^{+}$cells appeared as blue and red, respectively. The double-positive cells $\left(\mathrm{CD} 39^{+}\right.$FoxP $3^{+}$Treg cells) appeared as purple. As shown in Fig. $3 \mathrm{~A}, \mathrm{CD}^{3} 9^{+}$FoxP $3^{+}$Treg cells were principally scattered in the mesenchyma and parenchyma. Tumor tissues had a significantly higher Treg density as compared with paired peritumor tissues. The statistical graphs of $\mathrm{CD}_{39}{ }^{+} \mathrm{FoxP}^{+}$Treg cells also revealed higher Treg density in tumor tissues. Two representative cases of tumor tissues exhibited a high density of $\mathrm{CD} 39^{+}$FoxP3 $3^{+}$Treg cells (Fig. 3B and $\mathrm{C}$ ). In addition, the ratio of $\mathrm{CD} 39^{+} \mathrm{FoxP}^{+} / \mathrm{FoxP}^{+}$cells in tumor tissues was higher than that in paired peritumor tissues (70.97 vs. $69.41 \% ; \mathrm{P}=0.032$ ), indicating that $\mathrm{CD} 39^{+} \mathrm{FoxP}^{+}$ Treg cells could serve as a prognostic indicator in GC.

Prognostic significance of $\mathrm{FoxP}^{+}$and $\mathrm{CD} 39^{+} \mathrm{FoxP}^{+}$Treg cells in HCC. The univariate analysis demonstrated that tumor $\mathrm{FoxP}^{+}$and $\mathrm{CD} 39^{+} \mathrm{FoxP}^{+}$Treg cell counts were both correlated with OS (Fig. 4A and B), whereas peritumor FoxP3 ${ }^{+}$and $\mathrm{CD} 39^{+}$FoxP3 ${ }^{+}$Treg cell counts were not (Fig. 4C and D). Multivariate analysis using the Cox hazard model revealed that the levels of tumor FoxP3 ${ }^{+}$and $\mathrm{CD} 39^{+} \mathrm{FoxP}^{+}$ Treg cells were independent poor prognostic factors for OS. Furthermore, $\mathrm{CD}_{39}{ }^{+} \mathrm{FoxP}^{+}$Treg cells were a better prognostic indicator than FoxP3 ${ }^{+}$Treg cells for OS (hazard ratio, 1.919 vs. 0.385$)$.

\section{Discussion}

In the present study, CD39 expression was detected by IHC in tumor cells and Treg cells in tumor and peritumoral tissues of GC patients. When compared with paired peritumoral tissues, tumor tissues had higher expression of CD39, increased FoxP $^{+}$and $\mathrm{CD}^{+} 9^{+}$FoxP3 ${ }^{+}$Treg cell counts, and a higher ratio of $\mathrm{CD} 9^{+} \mathrm{FoxP}^{+} / \mathrm{FoxP}^{+}$Treg cells. The levels of CD39 expression were correlated with OS. In addition, tumor FoxP3 ${ }^{+}$ and $\mathrm{CD}_{39}{ }^{+} \mathrm{FoxP}^{+}$Treg cell counts had a prognostic role in OS. Additionally, CD $39^{+} \mathrm{FoxP}^{+}$Treg cells were a better prognostic indicator than FoxP3 ${ }^{+}$Treg cells for OS.

CD39 was first reported to be present on the surface of lymphocytes as well as endothelial cells by Kansas et al in 1991 (28). The following studies manifested that CD39 was a marker for cell activation in activated NK and T cells $(11,29)$. CD39 overexpression was reported in various cancers (19-21), but data on CD39 expression in GC was scarce. In the present study, CD39 expression was determined in GC using IHC, and it was observed that CD39 was primarily expressed in tumor tissues compared with paired peritumoral tissues. In addition, in tumor cell lines, CD39 expression in GC cell lines was higher than that in the gastric epithelial cell line.

Treg cells are crucial immunosuppressive cells in tumorigenesis and cancer development (25). Higher tumor infiltrated Treg counts correlate with poor prognosis in the majority of cancers, including GC $(25,26)$. In the immune system, CD39, a marker of Treg cells, plays a crucial role in hydrolyzing extracellular ATP, which is released by damaged cells and exhibits multiple pro-inflammatory effects (30). The expression of CD39 on FoxP3 ${ }^{+}$Treg cells is genetically driven and further upregulated at sites of inflammation (31). CD39 expressed in $\mathrm{CD} 4{ }^{+} \mathrm{CD} 25^{+}$Treg cells, along with CD73, catalyzes ATP/ADP to generate adenosine, which is important in mediating immune suppression (32). The development and immunosuppressive functions of $\mathrm{CD} 4^{+} \mathrm{CD} 25^{+}$FoxP $3{ }^{+}$Treg cells are influenced by the adenosine-A2A adenosine receptor pathway (33). In mice, CD39 is expressed in virtually all CD $4{ }^{+} \mathrm{CD} 25^{+}$Treg cells, and its catalytic activity is strongly enhanced by T-cell receptor ligation. In humans, CD39 expression is restricted to a subset of FoxP $3^{+}$regulatory effector/memory-like T cells (8). Human $\mathrm{CD} 4^{+} \mathrm{CD} 39^{+}$Treg cells produce immunosuppressive adenosine upon co-expression of surface CD73, which is consistent with the interaction of CD39 and CD73 in mice (34). High circulating $\mathrm{CD} 9^{+}$Treg cells predict poor survival for sepsis patients (35), and CD39-expressing FoxP $3^{+}$Treg cells are used as therapeutic targets in patients with psoriasis (36). In our study, it was observed that the cell counts of $\mathrm{CD}^{+} 9^{+} \mathrm{FoxP}^{+}$ cells in tumor tissue were higher than those in peritumor tissue. High CD39 expression was correlated with poor prognosis in resected GC. Furthermore, $\mathrm{CD} 39^{+} \mathrm{FoxP}^{+}$Treg cells were a better prognostic indicator than FoxP3 ${ }^{+}$Treg cells for OS in GC.

CD39 exhibits a homogeneous expression pattern within the FoxP3 ${ }^{+}$population in human diseases (36). Hilchey et al noticed that CD39+-infiltrating $\mathrm{T}$ cells increased in patients with follicular lymphoma, and contributed to adenosine-mediated $\mathrm{T}$ cell hyporesponsiveness (37). In sepsis, circulating CD39+ Treg cells in PBMC displayed a high percentage and mean fluorescence intensity compared with those in healthy subjects (35). In addition, high expression of CD39+ Treg cells correlated with severity and survival in sepsis patients (35). In PBMC of patients with head and neck cancer, the percentage of $\mathrm{CD}_{39}{ }^{+} \mathrm{FoxP}^{+} / \mathrm{FoxP}^{+}$Treg cells was $80 \%$, which was higher than that in normal subjects (38). In the current study, it was observed that the $\mathrm{CD} 39^{+} \mathrm{FoxP}^{+} / \mathrm{FoxP}^{+}$ratio in $\mathrm{GC}$ was $70.97 \%$, which was significantly higher than that in peritumor tissues. The abundant expression of CD39 and the higher $\mathrm{CD} 9^{+} \mathrm{FoxP}^{+} / \mathrm{FoxP}^{+}$ratio in $\mathrm{GC}$ indicated that the $\mathrm{CD} 39^{+}$ Treg levels could be used as a biomarker to predict GC outcome.

Taken together, our results indicate that CD39 expression in GC can predict patient outcome following radical resection as well as OS. The important prognostic value of CD39+ Treg cells in GC is highlighted. CD39 may serve as a promising therapeutic target for antitumor immunotherapy in GC.

\section{Acknowledgements}

The present study was supported by grants from the Science and Technology Commission Foundation of Pudong New Area (Shanghai, China; grant no. PKJ2011-Y02).

\section{References}

1. Jemal A, Bray F, Center MM, Ferlay J, Ward E and Forman D: Global cancer statistics. CA Cancer J Clin 61: 69-90, 2011.

2. Dunn GP, Old LJ and Schreiber RD: The three Es of cancer immunoediting. Annu Rev Immunol 22: 329-360, 2004.

3. Mittal D, Gubin MM, Schreiber RD and Smyth MJ: New insights into cancer immunoediting and its three component phases-elimination, equilibrium and escape. Curr Opin Immunol 27: 16-25, 2014. 
4. Vesely MD, Kershaw MH, Schreiber RD and Smyth MJ: Natural innate and adaptive immunity to cancer. Annu Rev Immunol 29: 235-271, 2011

5. Gao Q, Wang XY, Qiu SJ, Yamato I, Sho M, Nakajima Y, Zhou J, Li BZ, Shi YH, Xiao YS, et al: Overexpression of PD-L1 significantly associates with tumor aggressiveness and postoperative recurrence in human hepatocellular carcinoma. Clin Cancer Res 15: 971-979, 2009.

6. ShiGM,Ke AW, Zhou J, Wang XY,Xu Y,Ding ZB, DevbhandariRP, Huang XY, Qiu SJ, Shi YH, et al: CD151 modulates expression of matrix metalloproteinase 9 and promotes neoangiogenesis and progression of hepatocellular carcinoma. Hepatology 52: 183-196, 2010.

7. Thomas DA and Massagué J: TGF-beta directly targets cytotoxic $\mathrm{T}$ cell functions during tumor evasion of immune surveillance. Cancer Cell 8: 369-380, 2005.

8. Borsellino G, Kleinewietfeld M, Di Mitri D, Sternjak A, Diamantini A, Giometto R, Höpner S, Centonze D, Bernardi G, Dell'Acqua ML, et al: Expression of ectonucleotidase CD39 by FoxP $3^{+}$Treg cells: Hydrolysis of extracellular ATP and immune suppression. Blood 110: 1225-1232, 2007.

9. Dwyer KM, Deaglio S, Gao W, Friedman D, Strom TB and Robson SC: CD39 and control of cellular immune responses. Purinergic Signal 3: 171-180, 2007.

10. Zhou Q, Yan J, Putheti P, Wu Y, Sun X, Toxavidis V, Tigges J, Kassam N, Enjyoji K, Robson SC, et al: Isolated CD39 expression on $\mathrm{CD}^{+} \mathrm{T}$ cells denotes both regulatory and memory populations. Am J Transplant 9: 2303-2311, 2009.

11. Marcus AJ, Broekman MJ, Drosopoulos JH, Islam N Alyonycheva TN, Safier LB, Hajjar KA, Posnett DN, Schoenborn MA, Schooley KA, et al: The endothelial cell ecto-ADPase responsible for inhibition of platelet function is CD39. J Clin Invest 99: 1351-1360, 1997.

12. Plesner L: Ecto-ATPases: Identities and functions. Int Rev Cytol 158: 141-214, 1995.

13. Enjyoji K, Sévigny J, Lin Y, Frenette PS, Christie PD, Esch JS II, Imai M, Edelberg JM, Rayburn $\mathrm{H}$, Lech M, et al: Targeted disruption of cd39/ATP diphosphohydrolase results in disordered hemostasis and thromboregulation. Nat Med 5: 1010-1017, 1999.

14. Pulte ED, Broekman MJ, Olson KE, Drosopoulos JH, Kizer JR, Islam N and Marcus AJ: CD39/NTPDase-1 activity and expression in normal leukocytes. Thromb Res 121: 309-317, 2007.

15. Leal DB, Streher CA, Neu TN, Bittencourt FP, Leal CA, da Silva JE, Morsch VM and Schetinger MR: Characterization of NTPDase (NTPDase1; ecto-apyrase; Ecto-diphosphohydrolase; CD39; EC 3.6.1.5) activity in human lymphocytes. Biochim Biophys Acta 1721: 9-15, 2005.

16. Sun X, Wu Y, Gao W, Enjyoji K, Csizmadia E, Müller CE, Murakami T and Robson SC: CD39/ENTPD1 expression by $\mathrm{CD}^{+}{ }^{+} \mathrm{FoxP} 3^{+}$regulatory $\mathrm{T}$ cells promotes hepatic metastatic tumor growth in mice. Gastroenterology 139: 1030-1040, 2010.

17. Ring S, Oliver SJ, Cronstein BN, Enk AH and Mahnke K $\mathrm{CD} 4{ }^{+} \mathrm{CD} 25^{+}$regulatory $\mathrm{T}$ cells suppress contact hypersensitivity reactions through a CD39, adenosine-dependent mechanism. J Allergy Clin Immunol 123: 1287-1296.e2, 2009.

18. Goepfert C, Imai M, Brouard S, Csizmadia E, Kaczmarek E and Robson SC: CD39 modulates endothelial cell activation and apoptosis. Mol Med 6: 591-603, 2000.

19. Pulte D, Furman RR, Broekman MJ, Drosopoulos JH, Ballard HS, Olson KE, Kizer JR and Marcus AJ: CD39 expression on T lymphocytes correlates with severity of disease in patients with chronic lymphocytic leukemia. Clin Lymphoma Myeloma Leuk 11: 367-372, 2011.

20. Künzli BM, Bernlochner MI, Rath S, Käser S, Csizmadia E, Enjyoji K, Cowan P, d'Apice A, Dwyer K, Rosenberg R, et al: Impact of CD39 and purinergic signalling on the growth and metastasis of colorectal cancer. Purinergic Signal 7: 231-241, 2011.

21. Künzli BM, Berberat PO, Giese T, Csizmadia E, Kaczmarek E, Baker C, Halaceli I, Büchler MW, Friess H and Robson SC: Upregulation of CD39/NTPDases and P2 receptors in human pancreatic disease. Am J Physiol Gastrointest Liver Physiol 292: G223-G230, 2007.

22. Godbout JP and Glaser R: Stress-induced immune dysregulation: Implications for wound healing, infectious disease and cancer J Neuroimmune Pharmacol 1: 421-427, 2006.
23. Kono K, Kawaida H, Takahashi A, Sugai H, Mimura K, Miyagawa N, Omata $\mathrm{H}$ and Fujii $\mathrm{H}$ : $\mathrm{CD} 4\left(^{+}\right) \mathrm{CD} 25$ high regulatory $\mathrm{T}$ cells increase with tumor stage in patients with gastric and esophageal cancers. Cancer Immunol Immunother 55: 1064-1071, 2006

24. Ichihara F, Kono K, Takahashi A, Kawaida H, Sugai H and Fujii H: Increased populations of regulatory T cells in peripheral blood and tumor-infiltrating lymphocytes in patients with gastric and esophageal cancers. Clin Cancer Res 9: 4404-4408, 2003.

25. Perrone G, Ruffini PA, Catalano V, Spino C, Santini D, Muretto P, Spoto C, Zingaretti C, Sisti V, Alessandroni P, et al: Intratumoural FoxP3-positive regulatory $\mathrm{T}$ cells are associated with adverse prognosis in radically resected gastric cancer. Eur J Cancer 44: 1875-1882, 2008.

26. Cai XY, Wang XF, Li J, Dong JN, Liu JQ, Li NP, Yun B and Xia RL: Overexpression of CD39 and high tumoral CD39+/ $\mathrm{CD} 8^{+}$ratio are associated with adverse prognosis in resectable gastric cancer. Int J Clin Exp Pathol 8: 14757-14764, 2015.

27. Livak KJ and Schmittgen TD: Analysis of relative gene expression data using real-time quantitative PCR and the 2(-Delta Delta C(T)) method. Methods 25: 402-408, 2001.

28. Kansas GS, Wood GS and Tedder TF: Expression, distribution, and biochemistry of human CD39. Role in activation-associated homotypic adhesion of lymphocytes. J Immunol 146: 2235-2244, 1991.

29. Favaloro EJ: Differential expression of surface antigens on activated endothelium. Immunol Cell Biol 71: 571-581, 1993.

30. Dwyer KM, Hanidziar D, Putheti P, Hill PA, Pommey S, McRae JL, Winterhalter A, Doherty G, Deaglio S, Koulmanda M, et al: Expression of CD39 by human peripheral blood $\mathrm{CD}^{+} \mathrm{CD} 25^{+} \mathrm{T}$ cells denotes a regulatory memory phenotype. Am J Transplant 10: 2410-2420, 2010.

31. Rissiek A, Baumann I, Cuapio A, Mautner A, Kolster M, Arck PC, Dodge-Khatami A, Mittrücker HW, Koch-Nolte F, Haag F and Tolosa E: The expression of CD39 on regulatory $T$ cells is genetically driven and further upregulated at sites of inflammation. J Autoimmun 58: 12-20, 2015.

32. Deaglio S, Dwyer KM, Gao W, Friedman D, Usheva A, Erat A, Chen JF, Enjyoji K, Linden J, Oukka M, et al: Adenosine generation catalyzed by CD39 and CD73 expressed on regulatory $\mathrm{T}$ cells mediates immune suppression. J Exp Med 204: 1257-1265, 2007.

33. Ohta A, Kini R, Ohta A, Subramanian M, Madasu M and Sitkovsky M: The development and immunosuppressive functions of $\mathrm{CD} 4\left(^{+}\right) \mathrm{CD} 25\left(^{+}\right)$FoxP $3\left(^{+}\right)$regulatory $\mathrm{T}$ cells are under influence of the adenosine-A2A adenosine receptor pathway. Front Immunol 3: 190, 2012.

34. Schuler PJ, Saze Z, Hong CS, Muller L, Gillespie DG, Cheng D, Harasymczuk M, Mandapathil M, Lang S, Jackson EK and Whiteside TL: Human $\mathrm{CD} 4^{+} \mathrm{CD} 39^{+}$regulatory T cells produce adenosine upon co-expression of surface CD73 or contact with $\mathrm{CD} 73^{+}$exosomes or CD73 ${ }^{+}$cells. Clin Exp Immunol 177: $531-543,2014$

35. Huang H, Xu R, Lin F, Bao C, Wang S, Ji C, Li K, Jin L, Mu J, Wang Y, et al: High circulating $\mathrm{CD} 39\left(^{+}\right)$regulatory $\mathrm{T}$ cells predict poor survival for sepsis patients. Int $\mathbf{J}$ Infect Dis 30: 57-63, 2015.

36. Zhang HY, Yan KX, Huang Q, Ma Y, Fang X and Han L: Target tissue ectoenzyme CD39/CD73-expressing FoxP $3^{+}$regulatory $\mathrm{T}$ cells in patients with psoriasis. Clin Exp Dermatol 40: 182-191, 2015.

37. Hilchey SP, Kobie JJ, Cochran MR, Secor-Socha S, Wang JC, Hyrien O, Burack WR, Mosmann TR, Quataert SA and Bernstein SH: Human follicular lymphoma CD39+-infiltrating $\mathrm{T}$ cells contribute to adenosine-mediated $\mathrm{T}$ cell hyporesponsiveness. J Immunol 183: 6157-6166, 2009.

38. Mandapathil M, Lang S, Gorelik E and Whiteside TL: Isolation of functional human regulatory $\mathrm{T}$ cells (Treg) from the peripheral blood based on the CD39 expression. J Immunol Methods 346: 55-63, 2009. 